\title{
Intrastromal corneal ring segment implantation for ectasia after refractive surgery
}

\section{Implante de segmento de anel intraestromal de córnea para ectasia pós-cirurgia refrativa}

Larissa Rossana Souza Stival ${ }^{1}$, Belquiz R. do Amaral Nassaralla ${ }^{1,3}$, Marisa Novaes Falleiro Chaves de Figueiredo ${ }^{1}$, Frederico Bicalho ${ }^{4}$, JoÃO JORGE NASSARALLA JUNIOR ${ }^{1,2}$

\begin{abstract}
Purpose: To evaluate the clinical outcomes of intrastromal corneal ring segment (ICRS) implantation to correct ectasia in eyes with prior refractive surgery.

Methods: Forty-one eyes of 25 patients (13 men, 12 women; mean age, 28.66 years) with ectasia after refractive surgery [photorefractive keratectomy (PRK) or laser in situ keratomileusis (LASIK)] were included in a nonrandomized, retrospective, observational case series. Corneal tunnels were created by mechanical dissection in all eyes. Main outcome measures included uncorrected visual acuity (UCVA), best spectacle-corrected visual acuity (BCVA), refraction, keratometry, and computerized analysis of corneal topography. Patients were divided into two groups by the type of refractive surgery (Group A: PRK, Group B: LASIK).

Results: The mean preoperative manifest astigmatism decreased from -1.88 to -0.84 D in Group A $(p=0.096)$ and -3.18 to $-1.77 \mathrm{D}$ in Group B $(p=0.000)$. The mean keratometric astigmatism decreased from -2.58 to $-1.66 \mathrm{D}$ in Group $A(p=0.010)$ and -4.80 to $-2.78 \mathrm{D}$ in Group B $(p=0.000)$. The mean spherical equivalent decreased from -2.97 to -2.05 D in Group $A(p=0.065)$ and -3.31 to -2.42 D in Group B $(p=0.014)$. No significant between-group differences were noted on the comparison of preoperative and postoperative results. No intraoperative or postoperative complications were observed.
\end{abstract}

Conclusion: ICRS implantation is a useful treatment option for ectasia following refractive surgery, and it has significantly reduced the refractive cylinder and increased best spectacle-corrected visual acuity.

Keywords: Cornea/surgery; Corneal disease; Keratomileusis, laser in situ; Photorefractive keratectomy; Dilatation, pathologic; Refractive surgical procedures; Prostheses and implants

\section{RESUMO}

Objetivo: Avaliar os resultados do implante de anel intraestromal de córnea para correção de ectasia pós-cirurgia refrativa.

Métodos: Quarenta eum olhos de 25 pacientes, 13 homense 12 mulheres, comectasia pós-cirurgia refrativa (PRK ou LASIK) foram incluídos em um estudo não randomizado, retrospectivo e observacional. A média de idade no momento do implante do anel é de 28,66 anos. Em todos os olhos, o túnel corneano foi criado através da dissecção mecânica da córnea. Os resultados avaliaram acuidade visual sem correção (AVSC) e acuidade visual com correção (AVCC), refração, ceratometria e topografia corneana computadorizada. Os pacientes foram divididos em dois grupos de acordo com a cirurgia refrativa. Grupo A: PRK, Grupo B: LASIK.

Resultados: $A$ média do astigmatismo pré-operatório foi reduzida de -1,88 D para $-0,84$ D no grupo $A(P=0,096)$ e de $-3,18 D$ para $-1,77$ D no grupo $B(P=0,000)$. A média do astigmatismo ceratométrico foi reduzida de $-2,58 \mathrm{D}$ para $-1,66 \mathrm{D}$ no grupo $A(P=0,010)$ e de $-4,80$ para $-2,78 D$ no grupo $B(P=0,000)$. A média do componente esférico foi reduzida de -2,97D para-2,05 D no grupo $A(P=0,065)$ e de -3,31 D para-2,42 D no grupo $B(P=0,014)$. Nenhuma diferença estatisticamente significativa foi observada entre os grupos, quando se comparou os resultados do pré e pós-operatório. Não ocorreram complicações intra ou pós-operatórias.

Conclusão: $O$ implante de anel intraestromal de córnea é uma boa opção para o tratamento de ectasia pós-cirurgia refrativa, tendo resultado na redução significativa do astigmatismo refracional e melhora da acuidade visual com correção.

Descritores: Córnea/cirurgia; Doenças da córnea; Ceratomileuse assistida por excimer laserin situ; Ceratectomia fotorrefrativa;Dilatação patológica; Procedimentos cirúrgicos refrativos; Prótese e implantes

\section{INTRODUCTION}

Keratoconus (KCN) is a noninflammatory ectatic condition in which the cornea assumes a conical shape because of weakness, thinning, and anterior protrusion of the corneal surface ${ }^{(1-3)}$. A similar clinical entity may be observed in some patients following a refractive procedure [laser in situ keratomileusis (LASIK) or photorefractive keratectomy (PRK)] and is characterized by subsequent progressive corneal thinning and bulging, with topography similar to that of KCN. The exact incidence of post-refractive surgery ectasia remains unknown. Several parameters such as high myopic corrections, thin corneas, and residual corneal bed thickness less than $250 \mathrm{~mm}$ represent the major risk factors for this condition ${ }^{(4-7)}$.

Corneal ectasia is relatively rare after LASIK and PRK; however, it can have a profound negative effect on the refractive properties of the cornea. Therapeutic treatment options include gas-permeable lenses, corneal collagen crosslinking, and deep lamellar or penetrating keratoplasty ${ }^{(8)}$.

Intrastromal corneal ring segment (ICRS) implantation has added a new dimension to the management of keratectasia. In addition, long-term data for ICRS procedures indicate the possibility of deferring, or even replacing, keratoplasty in keratectasia patients ${ }^{(8,9)}$.

Several potential advantages exist for ICRS implantation over keratoplasty in eyes with ectasia after refractive surgery. First, it leaves the optical center of the cornea untouched, enhancing refractive outcomes. Second, it is reversible, in case of an unsatisfactory refractive or clinical outcome. Third, adjustments can be made using thinner or thicker rings. In case of unexpected corneal shape changes, one segment can be removed or exchanged. Fourth, it avoids complications of intraocular surgeries. Rings can be placed symmetrically or asymmetrically and oriented about the cone or based on a steep keratometric axis ${ }^{(9,10)}$. 
The purpose of this study was to evaluate the visual and keratometric outcomes of ICRS implantation for correcting and stabilizing corneal ectasia after refractive surgery.

\section{METHODS}

A nonrandomized, retrospective, observational case series was performed at the Goiania Eye Institute, Goiania, GO, Brazil. The charts of 25 patients ( 13 men and 12 women; mean age, 28.66 years, range 19-48 years) who underwent ICRS implantation to treat ectasia after refractive surgery were analyzed.

Exclusion criteria included history of herpes keratitis, corneal dystrophy, pregnancy or lactation, active anterior segment pathologic features, diagnosed autoimmune disease, systemic connective tissue disease, and acute or grade IV KCN. All patients were spectacle and contact lens intolerant.

Preoperative examinations included personal, medical, and ocular history; uncorrected visual acuity (UCVA); best spectacle-corrected visual acuity (BSCVA); refraction; keratometry; slit-lamp biomicroscopy; intraocular pressure (IOP) measurement by applanation tonometry (Haag Streit, Bern, Swiss); corneal astigmatism; surface regularity index; surface asymmetry index; corneal topography (Orbscan IIz, Technolas Perfect Vision GmbH); specular microscopy (Konan, Hyogo, Japan); and fundus examination (Sigma $150 \mathrm{~K}$, Heine, Germany).

Main outcome measures included UCVA, BSCVA, refraction, keratometry, and computerized analysis of corneal topography.

The institutional ethics committee of the Goiania Eye Institute approved the study. All patients provided written informed consent in accordance with the Declaration of Helsinki after receiving a detailed description of the nature and risks of the procedure.

\section{SuRgical PROCEDURE}

All surgeries were performed by the same surgeon (BAN) at the Goiania Eye Institute, between March 2005 and October 2013. ICRS implantation was indicated because of reduced BSCVA or contact lens intolerance. All surgeries were performed under topical anesthesia after miosis had been achieved with $2 \%$ pilocarpine. An eyelid speculum was used to expose the eye, and $2.5 \%$ povidone iodine eye drops were instilled into the cornea and conjunctival cul-de-sac. The visual axis was marked by pressing the Sinskey hook on the central corneal epithelium while asking the patient to fixate on the corneal light reflex of the microscope light.

For ICRS implantation, a 1.0-mm radial incision was made between the 5.0 and $7.0 \mu \mathrm{m}$ optical zones, on the most curved meridian of the cornea, according to preoperative topography. The diamond knife was calibrated at an $80 \%$ depth of the ultrasonic pachymetry at the incision site. Corneal tunnels were created by means of mechanical stromal dissection in all the eyes. The segments were circumferentially placed at the two-thirds depth of the peripheral corneal stroma. ICRS thickness and the implantation site were selected according to the extent of astigmatism and axis of the preoperative objective refraction in accordance with the nomogram provided by the manufacturer ${ }^{(11)}$

All the eyes were implanted using Cornealring (Visiontech Medical Optics, Belo Horizonte, MG, Brazil) or Ferrara Ring (Ferrara Ophthalmics, Belo Horizonte, MG, Brazil), according to the nomograms provided by the manufacturers.

The Cornealring segments consist of two semicircular micro-thin polymethylmethacrylate (PMMA) inserts of variable thickness (ranging from 0.15 to $0.35 \mathrm{~mm}$ ), with $90^{\circ}, 120^{\circ}, 160^{\circ}$, or $210^{\circ}$ of arc length as well as $4.7 \mathrm{~mm}$ inner and $5.9 \mathrm{~mm}$ outer diameters. The Ferrara Ring segments composed of PMMA Perspex CQ acrylic are available in thicknesses of $0.15,0.20,0.25$, and $0.30 \mathrm{~mm}$. The segment cross-section is triangular, and the base, for all thicknesses and diameters is $0.60 \mathrm{~mm}$, the segments are affered in $90^{\circ}, 120^{\circ}, 160^{\circ}$, or $210^{\circ}$ of arc.

Postoperatively, all the eyes received antibiotic-steroid combination eye drops four times per day for 2 weeks. In addition, all patients were instructed to use preservative-free artificial tears for lubrication frequently.

On the first postoperative day, slit-lamp biomicroscopic examination was performed to evaluate healing of the wound and migration of the segments. At the last follow-up examination, manifest refraction, UCVA and BSCVA, slit-lamp, and topographic examinations were performed.

\section{Statistical analysis}

Statistical analysis was performed using SPSS version 18.0 (SPSS, Inc.) software package. The paired $t$-test was used to check the significance of the difference between two dependent groups for every continuous variable. The level of statistical significance was set at p-value $<0.05$.

\section{RESULTS}

Forty-one eyes of 25 patients with postoperative keratectasia after PRK (8 eyes, Group A) and LASIK (33 eyes, Group B) were evaluated. The mean follow-up period was 32.73 months (range 3.80 months to 8.58 years).

The ICRS segment was uneventfully implanted in all cases. A single segment was implanted in 14 eyes (34.1\%) and double segments were implanted in 27 eyes (65.9\%) according to the normogram.

Table 1 shows details of the postoperative results from the last follow-up. The mean manifest astigmatism decreased from -1.88 D

Table 1. Comparison of preoperative and postoperative results

\begin{tabular}{|c|c|c|c|c|c|c|}
\hline \multirow[b]{2}{*}{ Parameter } & \multirow[b]{2}{*}{ Group } & \multicolumn{2}{|c|}{ Preoperative } & \multicolumn{2}{|c|}{ Postoperative } & \multirow[b]{2}{*}{$p$ value } \\
\hline & & Mean & \pm SD & Mean & \pm SD & \\
\hline \multirow[t]{3}{*}{ Mean BSCVA (logMAR) } & Group A & 0.30 & 0.21 & 0.11 & 0.06 & 0.022 \\
\hline & Group B & 0.43 & 0.16 & 0.17 & 0.11 & 0.000 \\
\hline & All patients & 0.41 & 0.17 & 0.16 & 0.10 & 0.000 \\
\hline \multirow[t]{3}{*}{ Mean manifest astigmatism (D) } & Group A & -1.88 & 1.56 & -0.84 & 0.83 & 0.096 \\
\hline & Group B & -3.18 & 2.08 & -1.77 & 1.36 & 0.000 \\
\hline & All patients & -2.93 & 2.04 & -1.59 & 1.32 & 0.000 \\
\hline \multirow[t]{3}{*}{ Mean keratometric astigmatism (D) } & Group A & -2.58 & 1.02 & -1.66 & 0.83 & 0.010 \\
\hline & Group B & -4.80 & 2.58 & -2.78 & 1.71 & 0.000 \\
\hline & All patients & -4.36 & 2.51 & -2.56 & 1.63 & 0.000 \\
\hline \multirow[t]{3}{*}{ Mean spherical equivalent (D) } & Group A & -2.97 & 2.12 & -2.05 & 1.98 & 0.065 \\
\hline & Group B & -3.31 & 3.20 & -2.42 & 2.71 & 0.014 \\
\hline & All patients & -3.24 & 3.00 & -2.34 & 2.57 & 0.003 \\
\hline
\end{tabular}

BSCVA= best spectacle-corrected visual acuity; $D=$ diopters; Group A= after PRK; Group B= after LASIK. 
preoperatively to $-0.84 \mathrm{D}$ postoperatively in Group A $(p=0.096)$ and -3.18 to $-1.77 \mathrm{D}$ in Group B ( $p=0.000)$. Only three eyes did not show successful reduction of corneal astigmatism. The mean manifest astigmatism decrease was statistically significant in Group B ( $p=0.000$; Figure 1).

The mean keratometric astigmatism decreased from -2.58 to $-1.66 \mathrm{D}$ in Group A ( $p=0.010)$ and -4.80 to $-2.78 \mathrm{D}$ in Group B ( $p=0.000)$. The mean spherical equivalent (SE) decreased from -2.97 to $-2.05 \mathrm{D}$ in Group A ( $p=0.065)$ and -3.31 to -2.42 D in Group B ( $p=0.014)$.

The mean BSCVA improved from 0.30 to 0.11 (logMAR) in Group A $(P=0.009)$ and 0.43 to 0.17 in Group B $(p=0.000)$. Four eyes maintained the preoperative BSCVA and 37 gained one to five lines of BSCVA. A mean gain of two lines in BSCVA was noted on comparing the preoperative measurements with the postoperative results at the last follow-up.

The mean maximum keratometry $\left(\mathrm{K}_{\max }\right)$ decreased from 45.34 to $43.75 \mathrm{D}$ in Group $\mathrm{A}(p=0.001)$ and 49.96 to $47.55 \mathrm{D}$ in Group B $(p=0.000)$. The mean minimum keratometry $\left(K_{\min }\right)$ decreased from 42.76 to 42.09 D in Group A ( $p=0.049$ ) and 45.17 to 44.77 D in Group $\mathrm{B}(p=0.068)$.

A between-group comparison is shown in table 2, which indicates that no statistically significant difference was found. The decrease in the mean manifest astigmatism was -1.03 D in Group A and -1.41 D in Group B ( $p=0.063)$. The mean reduction in keratometric astigmatism was $-0.91 \mathrm{D}$ in Group A and $-2.02 \mathrm{D}$ in Group B ( $p=0.842)$. The mean SE decrease was -0.92 D in Group A and -0.89 D in Group B $(p=0.858)$.

\section{Mean manisfest astigmatism reduction}

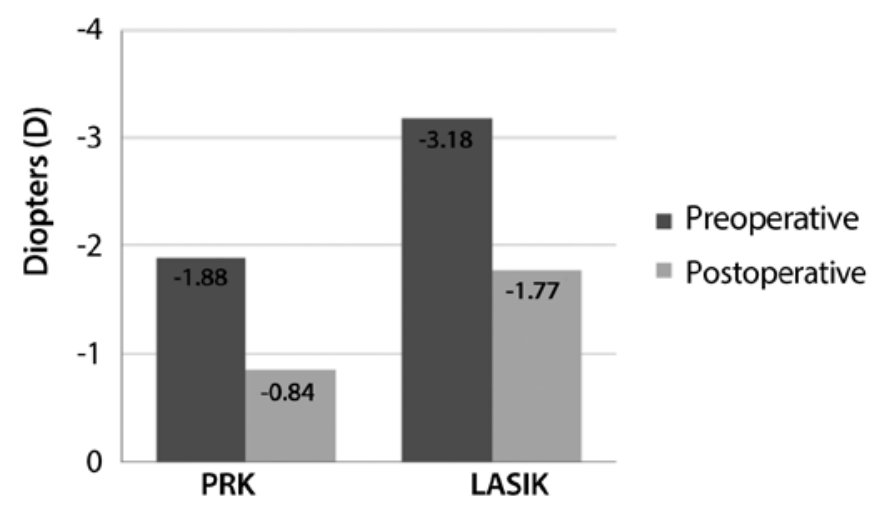

Figure 1. Preoperative $x$ postoperative results.

\section{DISCUSSION}

Over the last few years, there has been increasing concern regarding the occurrence of corneal ectasia after laser surgery. Although corneal ectasia is a rather rare occurrence after refractive surgery, being more frequent after LASIK than after PRK ${ }^{(12)}$, it can have a profoundly negative effect on the refractive properties of the cornea. The cornea begins to thin, and this may result in irregular astigmatism that leads to decreased visual acuity.

One possible alternative to manage corneal ectasia after laser refractive surgery is ICRS implantation, which was initially developed for the correction of myopia(13). Because of the removable and tissue-saving nature of this technique, its application can be extended to patients with corneal thinning disorders ${ }^{(1-3)}$. The insertion of additional material in the deep stroma induces a modification of the corneal curvature and corneal shape ${ }^{(13,14)}$. These midperipheral implants generate a central flattening effect because of the structure of the stromal collagen. The magnitude of this flattening effect is directly proportional to the thickness of the implant and inversely proportional to its diameter ${ }^{(14)}$. This corneal flattening induced by ICRS is particularly useful in ectatic corneal disease for minimizing corneal protrusion and consequently refractive error. However, it should be considered that the stromal structure is altered in the ectatic cornea and presents with a nonorthogonal lamellar architecture ${ }^{(15,16)}$.

Our results demonstrate that ICRS implantation is an effective treatment option for corneal ectasia, as reported previously in the literature ${ }^{(17,18)}$. The dramatic change in visual outcome and the stability of the results in terms of BSCVA and corneal topography after corneal ring implantation shows this is a suitable and effective treatment for ectasia after LASIK and PRK.

No intraoperative or delayed complications occurred. The integrity of the cornea was well preserved in all the eyes, and there was no evidence of ectasia or progressive thinning.

No significant changes were found in SE in both the groups. A mean change of -2.05 in Group A and -2.42 in Group B was observed, whereas a significant progressive reduction in manifest astigmatism was observed in Group B (mean change, -1.77 D). In contrast, other authors have reported significant reductions in SE with ICRS ${ }^{(19)}$. An explanation for this difference could be the great variability in preoperative SE observed in our sample, with mean SD of 3.24 D for all patients. In addition, no significant decrease in keratometric astigmatism was reported in Group A (mean change, -1.66); in contrast, it was significant in group B (mean change, -2.78). The significant astigmatic reduction found in our study supports the findings of previous studies ${ }^{(19,20)}$.

With regard to BSCVA, only Group B showed significant improvement at the last postoperative follow-up visit. Such an improvement was also reported in other previous series of post-LASIK ectasia with ICRS ${ }^{(21)}$, which confirms the adequate visual outcome provided by these implants in these ectatic corneas.

Table 2. Comparison between PRK and LASIK

\begin{tabular}{|c|c|c|c|c|c|}
\hline Parameter & Group & Preoperative & Postoperative & Reduction & $p$ value \\
\hline \multirow[t]{2}{*}{ Mean BSCVA (logMAR) } & Group A & 0.30 & 0.11 & -0.18 & 0.823 \\
\hline & Group B & 0.43 & 0.17 & -0.25 & \\
\hline Mean manifest astigmatism (D) & Group B & -3.18 & -1.77 & -1.41 & \\
\hline \multirow[t]{2}{*}{ Mean keratometric astigmatism (D) } & Group A & -2.58 & -1.66 & -0.91 & 0.842 \\
\hline & Group B & -4.80 & -2.78 & -2.02 & \\
\hline Mean spherical equivalent (D) & Group B & -3.31 & -2.42 & -0.89 & \\
\hline \multirow[t]{2}{*}{ Mean keratometry (Km) } & Group A & 44.05 & 42.92 & 1.13 & 0.842 \\
\hline & Group B & 47.56 & 46.16 & 1.40 & \\
\hline
\end{tabular}

$\mathrm{BSCVA}=$ best spectacle-corrected visual acuity; $\mathrm{D}=$ diopters; Group $\mathrm{A}=$ after PRK; Group B= after LASIK. 
A comparison between the preoperative and postoperative results of groups A and B did not reach statistical significance, and it could be attributed to the small number of patients in Group A.

There are some limitations to this study: the lack of a comparative group and the small sample of studied eyes (25 patients, 41 eyes) are the major limitations in determining the conclusiveness of our results. Future prospective comparative randomized studies with larger patient populations are required to clarify these crucial limitations of the present study.

Our postoperative results revealed a significant reduction in the magnitude of steepening of the anterior corneal surface, an increase in topographical regularity, and an improvement in BSCVA because of the better irregularity index and simultaneous partial correction of the residual refractive error.

Therefore, we suggest that ICRS implantation should be included in the treatment protocol for ectasia after refractive surgery because it is a safe and reversible procedure that preserves the visual axis of the cornea.

\section{CONCLUSIONS}

In conclusion, ICRS implantation in eyes with corneal ectasia after refractive surgery provides satisfactory visual outcomes and is a useful treatment option for corneal irregularity and astigmatism in post-LASIK and PRK corneal ectasia. These findings should be confirmed in larger comparative studies.

\section{REFERENCES}

1. Ucakhan OO, Kanpolat A, Ozdemir O. Contact lens fitting for keratoconus after Intacs placement. Eye Contact Lens. 2006;32(2):75-7.

2. Colin J, Cochener B, Savary CB, Malet F. Correcting keratoconus with intracornea rings. J Cataract Refract Surg. 2000;26(8):1117-22. Comment in: J Cataract Refract Surg. 2000;26(8):1099-100. J Cataract Refract Surg. 2001;27(3):341.

3. Colin J, Cochner B, Savary CB, Malet G, Holmes-Higgin D. Intacs inserts for treating keratoconus: one year results. Ophthalmology. 2001;108(8):1409-14.

4. Kymionis G, Bouzoukis D, Diakonis V, Tsoloços M. GkenosE, Pallikaris AL, et al. Long term results of thin corneas after refractive laser surgery. Am J Ophthalmol. 2007;144(2): 181-5. Comment in: Am J Ophthalmol. 2007;144(2):284-5.
5. Ou RJ, Shaw EL, Glascow BJ. Keratectasia after laser in situ keratomileusis (LASIK): evaluation of the calculated residual stromal bed thickness. Am J Ophthalmol. 2002; 1134(5):771-3

6. Amoils SP, Deist MB, Gous P, Amoils PM. latrogenic keratectasia after laser in situ keratomileusis for less than 4.0 to7.0 diopters of myopia. J Cataract Refract Surg. 2000; 26(7):967-77. Comment in: J Cataract Refract Surg. 2001;27(1):4; author reply 6-7.

7. McLeod SD, Kisla T, Caro NC, McMahon TT. Iatrogenic keratoconus: corneal ectasia following laser in situ keratomileusis for myopia. Arch Ophthalmol. 2000;1 18(2):282-4.

8. Torquetti L, Ferrara P. Intrastromal corneal ring segment implantation for ectasia after refractive surgery. J Cataract Refract Surg. 2010;36(6):986-90.

9. Kymionis GD, Diakonis VF, Kalyvianaki M, Portaliou D, Siganos C, Kozobolis VP, et al. One-year follow-up of corneal confocal microscopy after corneal cross-linking in patients with post laser in situ keratomileusis ectasia and keratoconus. Am J Ophthalmol. 2009;147(5):774-8.

10. Tan BU, Purcell TL, Torres LF, Schanzlin DJ. New surgical approaches to the management of keratoconus and post-LASIK ectasia. Trans Am Ophthalmol Soc. 2006;104: 212-20.

11. Tunc $Z$, Helvacioglu F, Sencan S. Evaluation of intrastromal corneal ring segments for treatment of post-LASIK ectasia patients with a mechanical implantation technique. Indian J Ophthalmol. 2011;59(6):437-43.

12. Seiler T, Koufala K, Richter G. latrogenic keratectasia after laser in situ keratomileusis. J Refract Surg. 1998;14(3):312-7.

13. Patel S, Marshall J, Fitzke FW 3rd. Model for deriving the optical performance of the myopic eye corrected with an intracorneal ring. J Refract Surg. 1995;11(4):248-52. Comment in: J Refract Surg. 1996;12(4):456-8.

14. Alio J, Salem T, Artola A, Osman A. Intracorneal rings to correct corneal ectasia after laser in situ keratommileusis. J Cataract Refract Surg. 2002;28(9):1568-74.

15. Meek KM, Tuft SJ, Huang Y, Gill PS, Hayes S, Newton RH, et al. Changes in collagen orientation and distribution in keratoconus corneas. Invest Ophthalmol Vis Sci. 2005; 46(6):1948-56.

16. Daxer A, Fratzl P. Collagen fibril orientation in the human corneal stroma and its implication in keratoconus. Invest Ophthalmol Vis Sci. 1997;38(1):121-9. Comment in: Invest Ophthalmol Vis Sci. 1997;38(7):1289-90

17. Uceda-Montanes A, Tomás JD, Alió JL. Correction of severe ectasia after LASIK with intracorneal ring segments. J Refract Surg. 2008;24(4):408-11.

18. Lovisolo CF, Fleming JF. Intracorneal ring segments for iatrogenic keratectasia after laser in situ keratomileusis or photorefractive keratectomy. J Refract Surg. 2002;18(5): 535-41.

19. Sharma M, Boxer Wachler BS. Comparison of single-segment and double-segment Intacs for keratoconus and post-LASIK ectasia. Am J Ophthalmol. 2006;141(5):891-5.

20. Pokroy R, Levinger S, Hirsh A. Single Intacs segment for post-laser in situ keratomileusis keratectasia. J Cataract Refract Surg. 2004:30(8):1685-95.

21. Uceda-Montanes A, Tomás JD, Alió JL. Correction of severe ectasia after LASIK with intracorneal ring segments. J Refract Surg. 2008;24(4):408-11. 